\title{
IDENTIFICATION OF SPATIAL-SETTLING STATUS OF RURAL AREAS OF SOUTHERN POLAND A CASE STUDY
}

\author{
Barbara Prus ${ }^{1}$, Stanislaw Bacior ${ }^{1}$, Malgorzata Dudzinska ${ }^{2}$ \\ ${ }^{1}$ University of Agriculture in Krakow, Poland; ${ }^{2}$ University of Warmia and Mazury in Olsztyn, Poland \\ b.prus@ur.krakow.pl, geomm@poczta.onet.pl,gosiadudzi@uwm.edu.pl
}

\begin{abstract}
A spatial range of urbanisation is visible in the size of geographic space used "in an urban way". In rural areas, spatial changes are mainly related to modifications to land use. The area of lands used agriculturally decreases in favour of built-up and urbanised areas including tourist and recreational lands, storage areas as well as commercial and service areas. Visible changes include the visual aspect and morphology of buildings due to the decreasing number of farm buildings and to the changing way of arrangement and density of buildings in rural areas. Modernisation of technical infrastructure takes place, including the development of transport network and its accompanying buildings as well as progress of the network of technical utility infrastructure (water distribution and sewage systems). An increase in the density of buildings and the floor area ratio, both vertical and horizontal, occurs in rural areas. There are some research questions, which factors most of all affect those urbanisation modifications? The aim of the paper is to assess the spatial-settling status of selected rural settlement units of southern Poland. Above all, the dependence between the density of buildings and the degree of coverage of the built-up and urbanised areas with housing developments in relation to the distance from an urban settlement was considered. Classification of the analysed objects by the spatial taxonomy method was performed to determine the similarity of settlement units in the spatial-settling aspect in the analysed area, which is important from the scientific point of view. The research was conducted in selected rural settlements in an area of Małopolskie Voivodeship in southern Poland.
\end{abstract}

Keywords: settlement unit, spatial taxonomy, urbanisation process, settlement geography, settlement density.

\section{Introduction}

As early as since mid-20th century, research has been carried out into urbanisation changes, which prove that in both developing and poorly developed countries urbanisation proceeds at a rapid pace $[1 ; 2 ; 3]$. The occurring changes, however, are not perceived as an opportunity for the developing countries, but as pressure directed particularly towards the areas used for agricultural purposes [4].

Boundaries of an area referred to as "urban" due to the categories of land use and to the form of improvements on land determine the physical space of urbanised areas, which often does not overlap with the statistical space delineated with boundaries of administrative units [5]. A developed and urbanised physical space will include both an area actually covered with buildings and an area outside high-density housing development that includes, inter alia, sidewalks, parking spaces, and squares [6].

The process, initiated in Great Britain as early as the 19th century, has become widespread throughout the world. As early as the beginning of the 20th century, the English and Welsh Census regarded as much as $80 \%$ of the population as urban [7]. The most striking manifestation of the high degree of urbanisation is the fact that in villages people, who do not work in agriculture, live [5]. Numerous settlements located along traffic routes have become a place of accommodation for people leaving towns and cities, and thus farmers have ceased to be the only inhabitants of villages. Thus, the previously applied distinction between the town and the village is losing its meaning [8;9].

The modern definition of urbanisation indicates the multi-dimensional summary of economic, social, demographic, and cultural processes and phenomena which, inter alia, lead to an increase in the urban space, and to the concentration of population within a smaller area [10]. Since the process of urbanisation changes has many aspects and is complex, its demographic, social, economic, spatial, environmental, and legal dimensions can be indicated [4]. This article only addresses the issue of the spatial dimension of urbanisation, which affects the rural areas. The problem will be noticeable in the size of geographic space used in an urban manner in villages. This dimension of urbanisation is referred to as landscape-and-physiognomic [11], spatial-settling [12], or architectural-and-spatial [13]. However, this is the same phenomenon. Spatial (urbanisation) changes in rural areas are primarily visible in the changes in land use, in particular in the area of agricultural production space decreasing at the expense of non-agricultural uses of land, including service and commercial, storage, or tourism and recreational areas. Land use is sometimes considered equivalent to land cover. It should be borne in mind, however, that land cover is meant as the biophysical element that actually occurs on the 
surface of land. On the other hand, land usage is defined as the actual space usage that reflects human activity in the landscape [14-16].

The function and physiognomy of buildings are also subject to changes in villages, as the number of buildings used for agricultural production purposes, referred to as farmsteads, decreases. In rural areas, there is an ongoing increase in the building density; in particular, the layout of buildings is changing, which results in an increase in their concentration. In developed countries, the village is becoming increasingly similar to the town. Research into the changes in the area of towns and cities in Poland indicates a clear relationship between the direction of changes and the size of a settlement unit measured by the number of population and the distance from an urban settlement [17].

The data on land cover in Poland include 12 classes of objects (level 2), including 35 various objects associated with land cover (level 3). These include: marine waters; flowing waters; standing waters; multi-family housing; single-family housing; industrial and storage development; commercial and service development; other types of development; forests; coppices; woodlots; mountain pine stands; shrubs; allotment gardens; plantations; orchards; forest nurseries; ornamental plant nurseries; grassy vegetation; crops cultivated on arable land; areas under roads for motor vehicles; areas under track formation; areas under airport roads; screes; taluses or rubbles; stony, sandy, or gravely areas; other unused land; squares; landfills for municipal and industrial wastes; headings; dumping grounds; areas under technical or construction equipment; and industrial and storage areas [18]. For the purposes of this study, the built-up and urbanised areas related to the development include areas with multi-family housing, single-family housing, commercial and service buildings, and other buildings.

The aim of the article is to identify the spatial-settling status of rural administration units (sections) by comparing this status with that of the urban settlement. An attempt was also made to outline the conditions responsible for the urbanisation changes taking place in the area under study.

\section{Materials and methods}

In the article, a method of classification diagnosis referred to as an initial analysis of the state of affairs was used. It provides an answer to the question as to what the tested phenomenon is, and determines the type of the unit based on the comparison of features. However, it requires further research concerning inter alia the specification, by means of a more accurate description, of unitary features of the phenomenon, determining its phase of development, and providing causal and teleological explanations including the determination of the predicted further development [19]. The classification diagnosis of the spatial-settling status was carried out for 34 sections of Miechów commune located in Powiat (district) of Miechów, in the northern part of Lesser Poland (Fig. 1), covering an area of $675.5 \mathrm{~km}^{2}$.
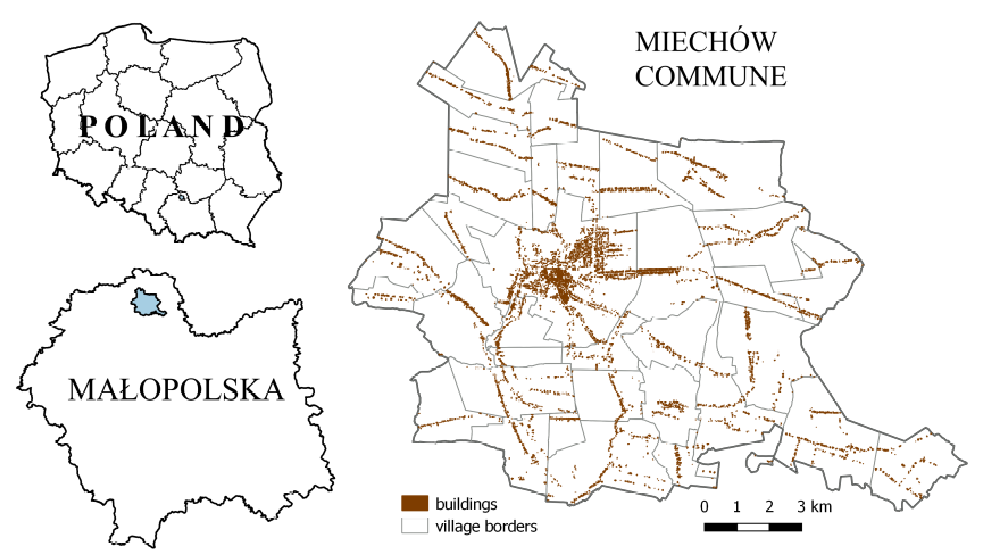

Fig. 1. Miechów commune compared to Poland and Małopolskie Voivodeship, distribution of buildings in sections of Miechów commune

The study was carried out in several stages. In the first stage, the building density index was calculated, which presents the number of residential, service and production buildings (codes in accordance with Polish classification of fixed assets: $1110,1230,1271)$ as per $1 \mathrm{~km}^{2}$. In the second stage, the floor area ratio in the residential buildings zone (code 1110), calculated as the surface area 
of residential buildings per the surface area of the built-up and urbanised zone, was analysed. The analysis concerned rural settlement units; however, an urban settlement unit was remained for calculations in order to emphasise certain features of the phenomenon under analysis. For the calculations of the density index and the floor area ratio, the Database of Topographic Objects BDOT10k was used, which includes in its content, i.e. transportation network, buildings (their location and functions), units of administrative division, and complexes of land use, all scaled in 1:10000. The data illustrate the status as of 2016. The research was carried out in the QGIS program using geoprocessing tools as well as data management tools (combination of attributes according to the location). For the calculations of basic statistics in particular localities, the Group Stats plugin was used. The analysis of building density index in localities of Powiat of Miechów was carried out using the density index [20], according to formula (1):

$$
d=\frac{n}{p},
$$

where $d$-density index

$n$ - number of objects within the spatial unit

$p$ - surface area of the spatial unit, in $\mathrm{km}^{2}$

In order to analyse the degree of coverage of the built-up and urbanised zone with housing developments, formula (2) was applied:

$$
d z=\frac{P m}{P z u},
$$

where $d_{z}$ - degree of coverage of the built-up and urbanised zone with housing developments

$P m$ - actual surface area of housing developments within the built-up and urbanised zone $P z u$ - surface area of the built-up and urbanised zone.

Natural breaks by the Jenks method into class intervals (6 intervals) enabled the spatial analysis of the phenomenon under study.

In the third stage, in order to determine the similarity between settlement objects in terms of the building density and the degree of coverage of the built-up and urbanised zone with housing developments, we used a metric in the form of Euclidean distance (most commonly used for this type of analysis). The smaller the calculated Euclidean distance, the similarity between the objects is greater. The basis for classification and separation of clusters of objects in 2-dimensional space features was the matrix of Euclidean distances. The procedure for classifying objects was carried out by the spatial taxonomy method, using a computer program called "Taksonomia Numeryczna" ("Numerical Taxonomy'). Spatial taxonomy is one of area-wide, hierarchical methods for classifying objects. The scheme of its operation was presented inter alia in a paper by Grabiński et al. [21]. It is based on the combination of interpenetrating hyperspheres generated for each object.

In the fourth stage, the obtained results were summarised.

\section{Results and discussion}

Stage 1. An analysis of the building density index. The improvements of land in Miechów commune are characterised by a considerable diversity in the density of buildings in particular localities. Most buildings are located in the town of Miechów, where the building density is 192.04 buildings per $\mathrm{km}^{2}$. The obtained building density index in 34 localities of Miechów commune ranges from 34.14 to 192.04 buildings per $\mathrm{km}^{2}$. The average value of this index in the area under study is 67.66 buildings per $\mathrm{km}^{2}$. The standard deviation is 26.23 buildings per $\mathrm{km}^{2}$, while the variation coefficient is $38.77 \%$, which indicates the average variation [22]. For most localities (i.e. 10 which accounts for over $29 \%$ of the total number of settlement units under analysis), the building density ranges from 66.91 to 78.32 buildings per $\mathrm{km}^{2}$. The extreme ranges (with extremely low and high values of the building density index) comprise the smallest number of objects. A range of values with the highest building density index in only noted in the town of Miechów. Four sections are characterised by the lowest range of the values of the building density index i.e. 34.14-45.63 buildings 
per $\mathrm{km}^{2}$. For four more sections, the density of buildings ranges from 78.32 to 98.67 buildings per $\mathrm{km}^{2}$. Further six sections are characterised by the density of $57.15-66.91$ buildings per $\mathrm{km}^{2}$, while for nine sections, the density of buildings ranges from 45.63 to 57.15 buildings per $\mathrm{km}^{2}$.

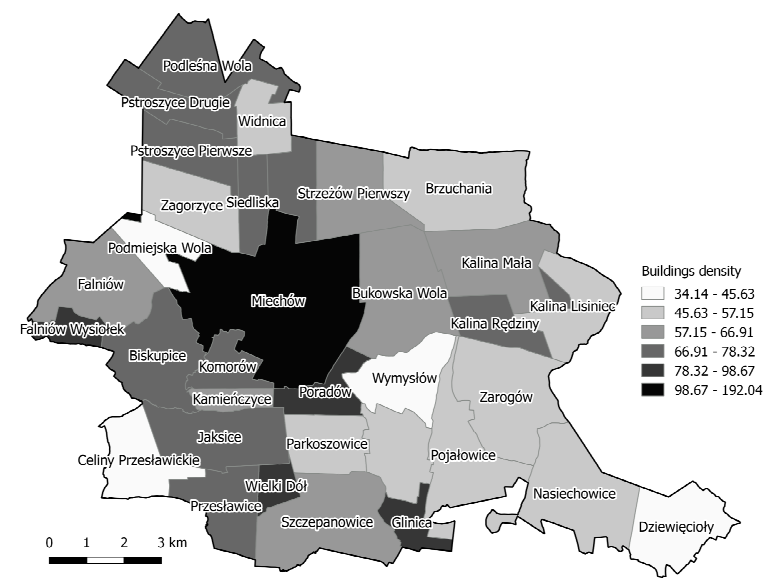

Fig. 2. Density of buildings in sections of Miechów commune, buildings per $\mathbf{k m}^{2}$

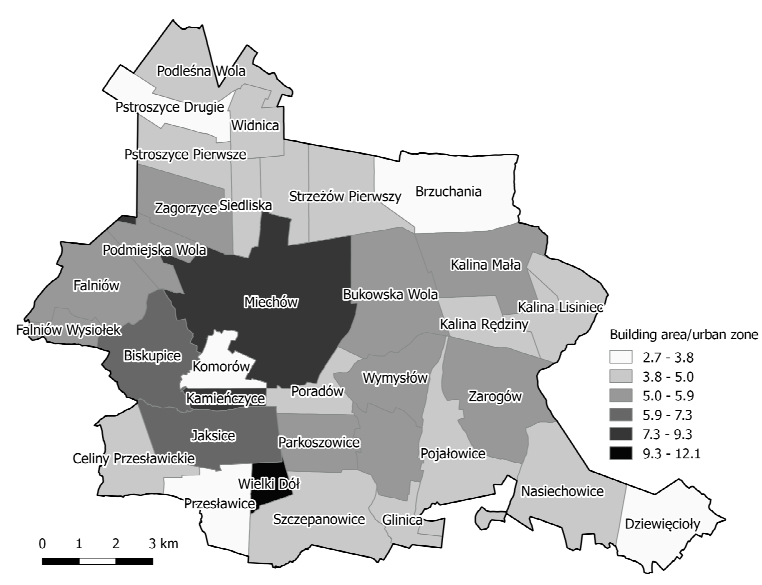

Fig. 3. Percentage of surface area of residential buildings in built-up and urbanised zone in sections of Miechów commune, \%

The dispersion of the index values has the hallmarks of normal distribution.

Stage 2. The degree of coverage of the built-up and urbanised zone with housing developments. The calculated percentage of the coverage with housing developments (with the actual area of the housing developments calculated along the outer contour) of the built-up and urbanised zone, which includes multi-family housing, single-family housing, industrial and storage development, commercial and service development, and other type of buildings, indicates a considerable diversity in particular localities of Miechów commune. This index ranges from 2.68 to $12.11 \%$. The average value amounts to $5.32 \%$, while the standard deviation only to $0.02 \%$, and the variation coefficient to $33.63 \%$, which indicates the average variation of the phenomenon under study in sections of Miechów commune. One section located in the southern part of the commune is characterised by the highest value of the calculated index. Five sections located near the boundaries with neighbouring communes are characterised by the lowest percentage of the actual area occupied by residential housing in relation to the built-up and urbanised area determined within the zones of land coverage. In 14 sections (i.e. approx $41 \%$ of the sections) the percentage of the calculated index ranges from 3.8 to $5.0 \%$.

Stage 3. Classification of homogeneous settlement units. The calculated values of the Euclidean distance range from 0.015 and 2.426. Having assumed the homogeneity assumptions resulting from the Euclidean distance value, the most similar localities include Strzeżów Drugi and Kalina Rędziny, which is also indicated by the results of classification by the spatial taxonomy method. Localities being most distant from each other (dissimilar) include the town of Miechów and the section of Celiny Przesławickie, which is indicated by the maximum value of the Euclidean distance. Visualisation of the results of classification performed using the spatial taxonomy method indicates a great variation of settlement units. The most distinctive object of the sections under analysis is the town of Miechów; however, there are several examples of heterogeneous units in the commune under analysis. The structure of similarity is very extensive, and the combinations of homogeneous units occur uniformly at all classification levels. The results also present the degree of urbanisation of particular sections, from "very low" to "very high". The town of Miechów is characterised by a high value of both the building density index and of the percentage of the actual surface area of buildings with the residential function in the built-up and urbanised zone. It can also be noticed that the sections located peripherally, on the outskirts of the commune, are characterised by the lowest degree of urbanisation. The sections adjacent to the town of Miechów are characterised by an intermediate degree of urbanisation. For comparison, an analysis of changes in the surface area of towns and cities in the years 1960-2003 demonstrated that with an increase in the number of 
population of a settlement unit, the percentage of units losing their built-up areas decreases, while the percentage of units which have increased spatially increases [17].

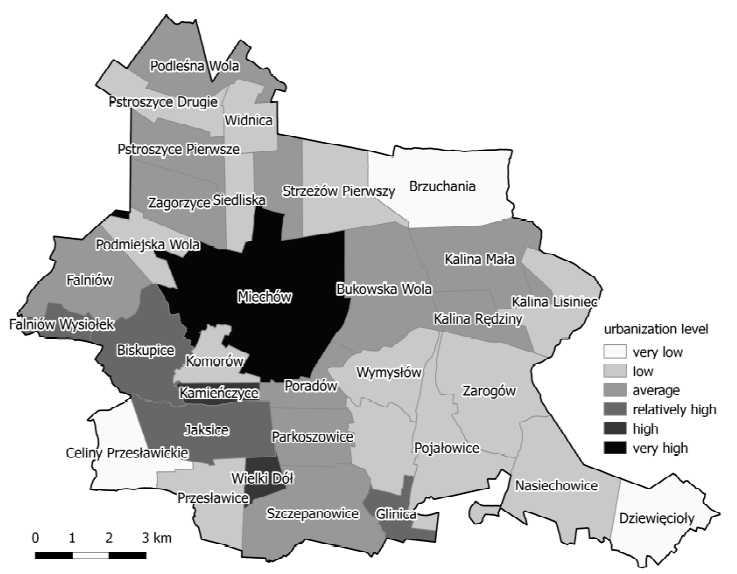

Fig. 4. Ranking of urbanisation degrees for sections of Miechów commune, calculated on basis of degree of coverage of built-up and urbanised zone with housing developments, and of building density

This situation is also confirmed by the most recent research, which indicates that suburban zones are the areas, in which dynamic changes due to human pressure can be observed, which cause the constant increase in the build-up areas [16;23]. The presented example of Miechów commune is not, therefore, an isolated case, and the issue requires further in-depth analyses.

\section{Summary and conclusions}

The analysis of the building density and of the coverage of the built-up and urbanised zone with residential housing enabled the determination of the degree of urbanisation of rural areas of settlement units located in one of the communes of southern Poland. The spatial-settling status of rural settlement units is largely determined by the distance to an urban settlement (due to economical and social causes), which was demonstrated by the analysis conducted on 34 sections of the urban-and-rural commune. It thus confirms the thesis, according to which the distance to an urban settlement determines the direction and rate of urbanisation changes in settlement units $[4 ; 16]$, expressed by the density of buildings (with the average density in the studied area 67.66 buildings per $\mathrm{km}^{2}$ ) and the residential floor area ratio in the built-up and urbanised zone (average value 5,32\%). The degree of advancement of urbanisation changes differentiates the Miechów commune sections under study. The many sections located in close proximity to the town are characterised by the highest degree of urbanisation, while those few located peripherally in relation to the urban settlement are characterised by the lowest one ( 3 villages). This state of affairs can be explained by the fact that rural settlements take over non-agricultural functions, including those related to satisfying the needs of inhabitants not involved in agricultural activities and living in rural areas. Given the state of Polish economy, in particular of agriculture, it can be assumed that in the spatial and settling context, the process of urbanisation will continue to go on not only in villages located close to the towns as we can observe on the Miechów case study. This is related to the development tendencies of settlement units striving to achieve a high infrastructural level, which is supposed to satisfy the demand for them among an ever-increasing circle of local communities (to meet the economic and social needs). Currently, urbanisation processes are characterised by a scale so large that organised, functional and spatial structures are formed, which are characterised by the concentration of not only the residential buildings themselves, but also of various types of activity and functions of areas. In Poland, the rapid rate of urbanisation changes is characterised by a phase related to the dynamic movement of people to rural areas and to smaller towns (what also can be observed on Miechów case study). This entails changes in the spatial and settling structure, including the adaptation of rural settlement units to the needs of local communities. 


\section{References}

[1] Hoselitz B.F., The role of cities in the economic growth of under-developed countries. Journal of Political Economy, 61, 1953, pp. 159-208.

[2] Turner R. (eds). India's Urban Future. University of California Press, Berkeley-Los Angeles. 1962.

[3] Breese G., Urbanization in Newly Developing Countries. Engelwood Cliffs, New York. 1966.

[4] Szymańska D., Geography of Settlement, Scientific Publisher Polish National Community, Warsaw. 2009. (In Polish)

[5] Smailes A.E., The Definition and Measurement of Urbanization [In:] Jones R. (eds) Essays on World Urbanization. London, 1975, pp. 1-19.

[6] Dziewoński K., The integration of statistical and cartographical analysis for research purposes. Regional Science Association Papers, 15, 1965, pp. 119-129. (In Polish)

[7] Smailes A.E., The urbanization of Britain. Problems of Applied Geography. Geographical Studies, 25, Polish Academy of Sciences, Warsaw, 1961, pp. 131-140.

[8] Gottmann J., Megalopoli. The urbanized north-eastern seaboard of the United States. The Twentieth Century Found, New York. 1961.

[9] Smailes A.E., The English Megalopolis. Proceedings of the Eleventh Pacific Science Congress, 10, Science Council of Japan, Tokyo. 1966.

[10] Węcławowicz G., Social geography of cities. Socio-spatial diversity, Scientific Publisher Polish National Community, Warsaw. 2003. (In Polish)

[11]Rakowski W., Urbanization processes of the village on the example of the Warsaw region. Studies of the Committee for Spatial Development of the Polish Academy of Sciences, Scientific Publisher Polish National Community, Warsaw. 1975. (In Polish)

[12] Andrzejewski A., Urbanization processes in the 80s and 90s. Bulletin of the Committee for Spatial Development of the Polish Academy of Sciences. 1991.

[13]Ziółkowski A., Urbanization, city, housing estate. Sociological studies. Scientific Publisher Polish National Community, Warsaw. 1965. (In Polish)

[14]Lambin E.F., Geist H., Rindfus R.R., Introduction: local processes with global impacts. [in:] Lambin E.F., Geist H. (eds) Land-use and land-cover change: Local processes and global impacts. Springer, Berlin. 2006.

[15] Bičík I., Kupková L., Jeleček L., Kabrda J., Štych P., Janoušek Z., Winklerová J., Land Use Changes in the Czech Republic 1845-2010. Socio-Economic Driving Forces. Springer Geography, Switzerland. 2015.

[16]Cegielska K., Kudas D., Różycka-Czas R., Salata T., Szylar M., The analysis of land cover macrostructure in the suburban area of Krakow. Geomatics, Landmanagement and Landscape 2, 2017, pp. 47-60.

[17] Szymańska D., Grzelak-Kostulska E., Hołowiecka B., Changes in the area and population density of Polish cities in the years 1960-2003 [In:] Słodczyk J., Szafranek E. (eds) Directions of the economic and socio-demographic transformation structure of cities, Publisher of the University in Opole, 2006. 341-353. (In Polish)

[18] Regulation of Minister of the Interior and Administration of 17 November 2011 on the topographic object database and the general geographic object and standard cartographic compilation database. (In Polish)

[19] Bielicki R. Selected interpretive aspects of diagnoses. Gdańsk Studies. Visions and reality. T. VII, 2010, pp. 173-184. (In Polish)

[20] Kostrubiec B. Analysis of concentration phenomena in the network, Publisher of the Polish Academy of Sciences, Wrocław, geographical works 1972. No. 93. (In Polish)

[21] Grabiński T., Wydymus S., Zeliaś A. Methods of numerical taxonomy in modeling of socioeconomic phenomena. Scientific Publisher Polish National Community, Warsaw. 1989. (In Polish)

[22] Kolenda M. Numeric taxonomy. Classification, ordering and analysis of multi-feature objects [In Polish]. Publisher of University of Economics, Wrocław. 2006. (In Polish)

[23] Gonda-Soroczyńska E., Transformations of the suburban zone of Wrocław in the last decade. Infrastructure and Ecology of Rural Areas, 4, 2009, pp. 149-165. (In Polish) 